\title{
Cloning and expression of gene FanC-2NT encoding K99-2NT fimbrial antigen of enterotoxigenic Escherichia coli from diarrheic post-weaning piglets
}

\author{
NGUYEN HOANG LOC ${ }^{1 *}$ \\ LE MY TIEU NGOC ${ }^{1}$ \\ DOAN THI TAM ${ }^{1}$ \\ TRAN THUY LAN ${ }^{2}$ \\ DINH THI BICH LAN ${ }^{2}$ \\ PHUNG THANG LONG ${ }^{3}$ \\ ${ }^{1}$ College of Sciences and Institute of Biotechnology \\ belong to Hue University \\ ${ }^{2}$ Institute of Biotechnology \\ ${ }^{3}$ College of Agriculture and Forestry, Hue University, \\ Hue 530000, Vietnam \\ *Corresponding author \\ Nguyen Hoang Loc \\ Email:nhloc@hueuni.edu.vn
}

List of any nonstandard abbreviations

SM: DNA size marker

MW: protein weight marker

Keywords: E. coli, fimbriae, fanC-2NT, K99-2NT, piglet

Received March 25, 2015

Revised October 15, 2015

Accepted November 16, 2015

\begin{abstract}
Background and Purpose: The K99 (F5) is one pilus adhesin that mediates the attachment of enterotoxigenic E. coli (ETEC) strains to small intestines to cause to diarrhea in piglets, lambs and newborn calves. In this work, we carried out cloning and expression of the mature peptide of FanC subunit, K99 fimbriae, one of the most common adhesive antigens in E. coli.

Materials and Methods: E. coli 2NT strain was isolated from fecal samples of post-weaning piglets with diarrhea. The coding sequence of the mature peptide of K99-2NT subunit was isolated by PCR amplification and cloned into $p G E M^{\circ}-T$ Easy vector for sequencing using fluorescent dideoxy-terminator method. Expression of K99-2NT protein which was inserted into $p E T 200 / D-T O P O$ vector induced with IPTG. The PCR product and expression level of protein was examined by agarose gel electrophoresis and sodium dodecyl sulfate-polyacrylamide gel electrophoresis, respectively.
\end{abstract}

Results and Conclusions: We cloned and expressed successfully the mature peptide of K99 subunit with molecular weight of approximately 17.5 $k D$ a from E. coli $2 N T$ strain (named K99-2NT). Nucleotide sequence of the K99-2NT subunit coding region offanC-2NT gene is 477 bp in length and is 99\% similarity with that of fan C gene (accession no: M35282). Highest expression level occurred after $12 \mathrm{~h}$ of induction with $0.75 \mathrm{mM}$ $I P T G$ at $37^{\circ} \mathrm{C}$. This subunit antigen will be tested for immune response of rat in the next time.

\section{INTRODUCTION}

The K99 (F5) is one pilus adhesin that mediates the attachment of enterotoxigenic $E$. coli (ETEC) strains to small intestines to cause to diarrhea in piglets, lambs and newborn calves (1). The ETEC enters the small intestine and binding to the specific receptors on the surface of epithelial cells through the K99 (2). The surface antigen K99 wrapped around each other in a fibrous to create flexible helical structure (3). There are 8 different genes involved in the expression of antigen $\mathrm{K} 99$, from fan $A$ to $\mathrm{fanH}$, with the corresponding proteins from FanA to FanH (2). Among them, FanA and FanB hold regulatory functions, FanC is a large subunit and is also adhesive component, FanD is the protein of outer membrane, FanE is chaperone of outer membrane (4), FanG and FanH is small subunits (5), FanF roles in the initiation and prolonged structure of K99 (6). 
Some $\operatorname{fan} C$ genes encoding $\mathrm{K} 99$ fimbriae were cloned from various $E$. coli strains reported by Roosendaal et al (7), Li et al (8), Yang et al (9), Tahamtan et al (unpublished, accession no: GU951525), and Nasiri et al (unpublished, accession no: KP054295). Recombinant K99 fimbriae also expressed in Lactobacillus acidophilus (10), Lactobacillus casei (11), various E. coli strains (9, 12, 13, $14)$, and soybean $(15,16)$.

In previous reports, we have successfully cloned and expressed fimbrial proteins such as F4 (F107-C), F18 (K88-1NT) and F6 (987P, FasA-13NT) in E. coli BL21 (DE3) cells $(17,18)$. In this work, we present the results of cloning and expression of the mature peptide of FanC subunit, K99 (F5) fimbria, one of the most common adhesive antigens in E. coli.

\section{MATERIALS AND METHODS}

\section{Bacterial strain}

E. coli $2 \mathrm{NT}$ strain was isolated from fecal samples of post-weaning piglets with diarrhea originating from unvaccinated herds in the territory of Thua Thien Hue province, Vietnam (17). Toxicity of strain 2NT was tested by the method described by Carter (19).

\section{DNA isolation and PCR amplification of the fimbrial subunit gene}

Genomic DNA of E. coli 2NT was isolated by phenol extraction method (20) and used as template in PCR amplification with the specific primers (K99F-5'-CACCAATACAGGTACTATTAACTTAATG-3' and K99R-5'CATATAAGTGACTAAGAAGG-3'), which designed to base on the coding DNA sequence (CDS) for the mature peptide of $\mathrm{K} 99$ subunit gene $(\mathrm{fan} C)$ (accession no: M35282). To enable directional cloning in the further, the forward primer contains the CACC sequence (adapter) at the 5 'end. These four nucleotides will base pair with the GTGG overhang sequence in pET200/D-TOPO vector (Invitrogen).

The PCR component consisted of 80 ng template DNA, $6 \mu \mathrm{l} 2 \times$ PCR master mix (Fermentas), and $10 \mathrm{pmol}$ each primer. Distilled water was added to a final volume of $12 \mu$. Template DNA was denaturated at $95^{\circ} \mathrm{C}$ for 5 min; 35 cycles of $1 \mathrm{~min}$ for denaturation at $95^{\circ} \mathrm{C}, 1 \mathrm{~min}$ for annealing at $55^{\circ} \mathrm{C}$ and $1 \mathrm{~min}$ for polymerization at $72^{\circ} \mathrm{C}$ were performed in the thermocycler (iCycler, Bio$\mathrm{Rad})$. After the final cycle, the temperature of $72^{\circ} \mathrm{C}$ was held for an additional $10 \mathrm{~min}$.

PCR product was tested by $0.8 \%(\mathrm{w} / \mathrm{v})$ agarose gel electrophoresis and the gel was stained with $0.5 \mu \mathrm{g} / \mathrm{l}$ ethidium bromide solution. Electrophoresis image was analyzed by Gel Documentation system (BioRad).

\section{Cloning and sequencing of the fimbrial subunit gene}

The PCR product was inserted into pGEM $^{\circledR}-\mathrm{T}$ Easy vector (Promega), the ligation component consisted of 50 ng vector, $5 \mu$ l buffer, 3 unit T4 DNA ligase, and $25 \mathrm{ng}$ PCR product. Distilled water was added to a final volume of $10 \mu \mathrm{l}$. The ligation was incubated at $25^{\circ} \mathrm{C}$ for $1 \mathrm{~h}$, and at $4^{\circ} \mathrm{C}$ overnight, then transformed into $E$. coli $\mathrm{DH} 5 \alpha$ cells by the heat-shock method (20). Recombinant pGEM ${ }^{\circledR}$-T Easy vector was extracted by AccuPrep ${ }^{\circledR}$ Plasmid Mini Extraction Kit (Bioneer) and the PCR product was sequenced by the method of fluorescent dideoxy-terminator on $3130 \mathrm{ABI}$ system (Applied Biosystem).

\section{Expression of the fimbrial subunit gene}

The PCR product (gene coding fimbrial protein) from recombinant $\mathrm{pGEM}^{\circledR}$-T Easy vector was cut out from $0.8 \%$ agarose gel and purified by Wizard ${ }^{\circledR}$ SV Gel and PCR Clean-Up System Kit (Promega), and then ligated to a $\mathrm{pET} 200 / \mathrm{D}-\mathrm{TOPO}$ vector harboring T7 promoter (Invitrogen). The ligation component consisted of $20 \mathrm{ng}$ vector, $1 \mu \mathrm{l}$ salt solution, and $4 \mathrm{ng}$ PCR product. Distilled water was added to a final volume of $6 \mu$ l. The ligation was incubated at $25^{\circ} \mathrm{C}$ for $60 \mathrm{~min}$. Recombinant pET200/DTOPO vector was then transformed into $E$. coli $\mathrm{Star}^{\mathrm{TM}}$ BL21 (DE3) cells (Invitrogen) according to the manufacturer's instructions.

Expressions of $\mathrm{K} 99$ fimbrial subunit was performed in E. coli BL21 Star ${ }^{\mathrm{TM}}$ (DE3) cells at $37^{\circ} \mathrm{C}$ on LB medium supplemented with $1 \%$ glucose and $50 \mu \mathrm{g} / \mathrm{ml}$ kanamycin. The culture was carried out on a rotation shaker with speed of $200 \mathrm{rpm}$ to an OD600 of 0.8. Isopropyl $\beta$-D-1-thiogalactopyranoside (IPTG) was added to a final concentration of $0.5 \mathrm{mM}$ for induction. An induction time was extended from 2 to $8 \mathrm{~h}$, and the cell biomass was harvested by centrifugation at $8000 \mathrm{rpm} / 4^{\circ} \mathrm{C}$ for $1 \mathrm{~min}$. The freezing and thawing at $42^{\circ} \mathrm{C}$ was performed with three repeats to break cells and total soluble protein was obtained by extraction buffer $\left(50 \mathrm{mM} \mathrm{K}_{3} \mathrm{PO}_{4} \mathrm{pH} 7.8,400 \mathrm{mM} \mathrm{NaCl}, 100 \mathrm{mM}\right.$ $\mathrm{KCl}, 10 \%$ glycerol and $0.5 \%$ Trixton X-100). Expression level of K99 fimbrial subunit was assayed by electrophoresis on $12 \%(\mathrm{w} / \mathrm{v})$ polyacrylamide gel with sodium dodecyl sulfate (SDS-PAGE). The gel was then stained with Coomassie Blue R-250 and image was analyzed by Quality One software (ver 4.1, BioRad).

\section{RESULTS AND DISCUSSION}

\section{Cloning and sequencing of the fimbrial subunit gene}

Figure 1A showed PCR product is of expected size of approximately $480 \mathrm{bp}$ from $E$. coli $2 \mathrm{NT}$ strain. This size is similar with that of the mature peptide coding sequence of $\operatorname{fan} C$ gene (accession no. M35282). PCR product was purified and inserted into $\mathrm{pGEM}{ }^{\circledR}-\mathrm{T}$ Easy vector, 
A

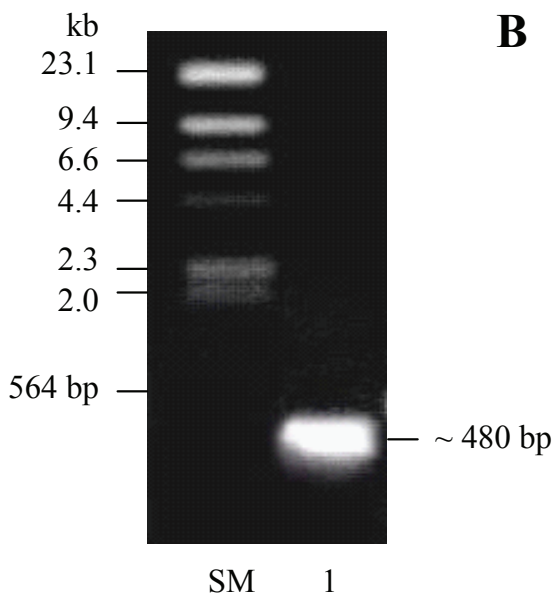

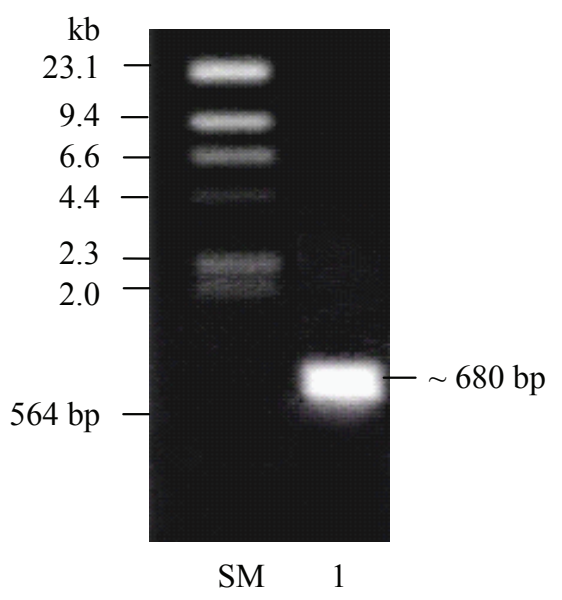

Figure 1. PCR amplification of the mature peptide coding sequence of fan $C-2 N T$ gene (accession number: JX987524) from genomic DNA of E. coli $2 N T$ strain. SM: DNA size marker (lambda/HindIII), I(A): PCR product of K99-F/ K99-R specific primer pair, 1(B): PCR product of $M 13$ primer pair of $p G E M^{\circledR}-T$ Easy vector.

\begin{tabular}{|c|c|c|c|}
\hline JX987524 & 1 & AATACAGGTACTATTAACTTCAATGGCAAAATAACGAGTGCTACTTGTACAATTGAGCCT & 60 \\
\hline M35282 & 136 & AATACAGGTACTATTAACTTCAATGGCAAAATAACGAGTGCTACTTGTACAATTGACCCT & 195 \\
\hline JX987524 & 61 & GAGGTCAATGGTAATCGTACATCAACTATAGATCTTGGGCAGGCTGCTATTAGT & 120 \\
\hline M35282 & 196 & GAGGTCAATGGTAATCGTACATCAACTATAGATCTTGGGCAGGCTGCTATTAGTGGTCAT & 255 \\
\hline JX987524 & 121 & GGCACTGTAGTGGATTTTAAACTAAAACCAGCGCCCGGCAGTAATGACTGCCTAGCGAAA & 180 \\
\hline M35282 & 256 & GGCACTGTAGTGGATTTTAAACTAAAACCAGCGCCCGGCAGTAATGACTGCCTAGCGAAA & 315 \\
\hline JX987524 & 181 & GTCTGGTTCTATGAACAGTTTAGGTTTTAATAATAC & 240 \\
\hline M35282 & 316 & ACAAATGCTCGTATTGACTGGTCTGGTTCTATGAACAGTTTAGGTTTTAATAATACAGCT & 375 \\
\hline JX987524 & 241 & TCAGGAAATACTGCTGCTAAAGGATACCATATGACTTTGCGCGCAACAAACGTTGC & 300 \\
\hline M35282 & 376 & 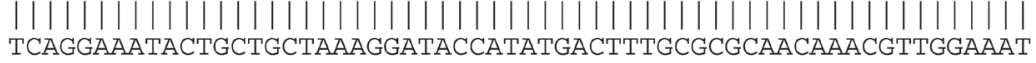 & 435 \\
\hline JX987524 & 301 & GGGTCTGGTGGTGCTAATATTAATACTTCATTCACTACGGCTGAATACACTCACACTTCT & 360 \\
\hline M35282 & 436 & GGGTCTGGTGGTGCTAATATTAATACTTCATTCACTACGGCTGAATACACTCACACTTCT & 495 \\
\hline JX987524 & 361 & GCAATTCAGTCATTTAACTATTCAGCCCAGCTGAAAAAAGATGACCGCGCTCCGTC & 420 \\
\hline & & | | | & \\
\hline M3 5282 & 496 & GCAATTCAGTCATTTAACTATTCAGCCCAGCTGAAAAAAGATGACCGCGCTCCGTCTAAT & 555 \\
\hline JX987524 & 421 & 'GTATTTACTACTTCAGCATCCTTCTTAGTCACTTATATG & 477 \\
\hline 135282 & 556 & GGTGGATATA & 612 \\
\hline
\end{tabular}

Figure 2. Multiple alignment of the mature peptide coding sequence of the fanC-2NT gene (accession no: JX987524) and that of fanC gene (accession no: M35282) with a homology of $99 \%$.

and then employed into E. coli DH5 $\alpha$ cells. The presence of the insert in transformed bacterial cells was determined by PCR amplification with M13 primers of vector. The results showed the DNA band is approximately 680 bp in length (480 bp of insert and 200 bp of primer regions on vector) (Fig 1B).

Nucleotide sequence of the insert (PCR product) was analyzed to verify the cloned gene. In this study, the mature peptide coding sequence of fan $C$ gene from $E$. coli $2 \mathrm{NT}$ strain (named fanC-2NT) is $477 \mathrm{bp}$ in length and is $99 \%$ similarity with fanC gene (Fig 2). The fanC-2NT gene was deposited in the NCBI with accession number of JX987524 and it's protein ID is AGD79963.1.

A nucleotide change of fan $\mathrm{C}-2 \mathrm{NT}$ affected the encoded amino acid, in which 19th amino acid (aspartic acid, D) of $f a n C$ gene is replaced by glutamic acid (E) (Fig 3). The difference was probably due to natural variants among $E$. coli strains. Generally, the sequence analysis demonstrated a very high similarity of the cloned gene, $\operatorname{fan} C-2 \mathrm{NT}$, to the $\operatorname{fan} C$ gene. 


$\begin{array}{llll}\text { AGD79963 } & 1 & \text { NTGTINFNGKITSATCTIEPEVNGNRTSTIDLGQAAISGHGTVVDFKLKPAPGSNDCLAK } & 60 \\ \text { AAA24038 } & 1 & \text { NTGTINFNGKITSATCTIDPEVNGNRTSTIDLGQAAISGHGTVVDFKLKPAPGSNDCLAK } & 60 \\ \text { AGD79963 } & 61 & \text { TNARIDWSGSMETNSLGFNNTASGNTAAKGYHMETTLRATNVGNGSGGANINTSFTTAEY } & 120 \\ \text { AAA24038 } & 61 & \text { TNARIDWSGSMETNSLGFNNTASGNTAAKGYHMETTLRATNVGNGSGGANINTSFTTAEY } & 120 \\ & & & \\ \text { AGD79963 } & 121 & \text { THTSAIQSFNYSAQLKKDDRAPSNGGYKAGVFTTSASFLVTYMET } & 165 \\ \text { AAA24038 } & 121 & \text { THTSAIQSFNYSAQLKKDDRAPSNGGYKAGVFTTSASFLVTYMET } & 165\end{array}$

Figure 3. Comparison of the deduced amino acid sequence of two K99-2NT (protein ID: AGD79963.1) and K99 (protein ID: AAA24038.1) fimbrial subunits.

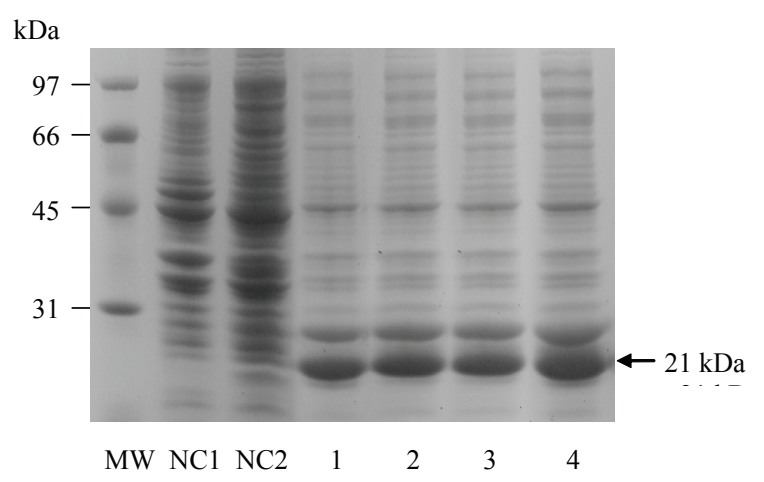

Figure 4. Expression of K99-2NT fimbrial subunit in E. coli BL21 (DE3) cell was induced by $0.5 \mathrm{mM} \mathrm{IPTG.} \mathrm{MW:} \mathrm{protein} \mathrm{weight}$ marker (97-14.4 kDa), NC1: non-transformated E. coli cells, NC2: transformated E. coli cells without induction, 1-4: expression of K99-2NT subunit after 2-8 h of induction, respectively.

\section{Expression of the fimbrial subunit gene}

Recombinant pET 200/D-TOPO vector harboring the fanC-2NT gene was subjected to PCR amplification to determine the insertion (data not shown). Expression of the fan $C-2 \mathrm{NT}$ gene in $E$. coli was expected to produce the FanC-2NT protein (also known as K99-2NT) of approximately $21 \mathrm{kDa}(17.5 \mathrm{kDa}$ of K99-2NT subunit and $3.7 \mathrm{kDa}$ of fusion fragment of pET 200/D-TOPO vector).

Recombinant K99-2NT protein was analyzed through SDS-PAGE. For the inclusion body fraction, strong band of $21 \mathrm{kDa}$ was obtained in culture induced with $0.5 \mathrm{mM}$ IPTG (Fig 4). Protein band of K99-2NT subunit in unsoluble fractions are very weak (data not shown). For the uninduced cells, no protein band of expected size was observed, suggesting that induction with IPTG is required for expression of fanC-2NT fimbrial subunit gene.

\section{Effect of IPTG concentration and induction time on expression level of the fimbrial subunit gene}

For the expression vector with T7 lac promoter (pET 200/D-TOPO), final IPTG concentration should be optimized because of its great contribution to recombinant protein expression and serious harm to cell growth. We investigated the effect of IPTG at different concentrations on recombinant protein production in E. coli cells. IPTG concentrations from 0.05 to $2 \mathrm{mM}$ used to induce expression of K99-2NT subunit after 5 h. Comparison of intensity of the bands in SDS-PAGE showed that $0.75 \mathrm{mM}$ IPTG is suitable for higher expression of K99-2NT subunit (Fig 5).

After adding the IPTG into the medium, the target protein begins to be synthesized and induction time is necessary for recombinant protein production. In our study, the optimal induction time for expression was examined by analyzing samples taken in every $2 \mathrm{~h}$, from 2 to $14 \mathrm{~h}$, after induction with $0.75 \mathrm{mM} \mathrm{IPTG}$ at $37^{\circ} \mathrm{C}$. Figure 6 shown highest expression of K99-2NT subunit occurred after $12 \mathrm{~h}$ of induction.

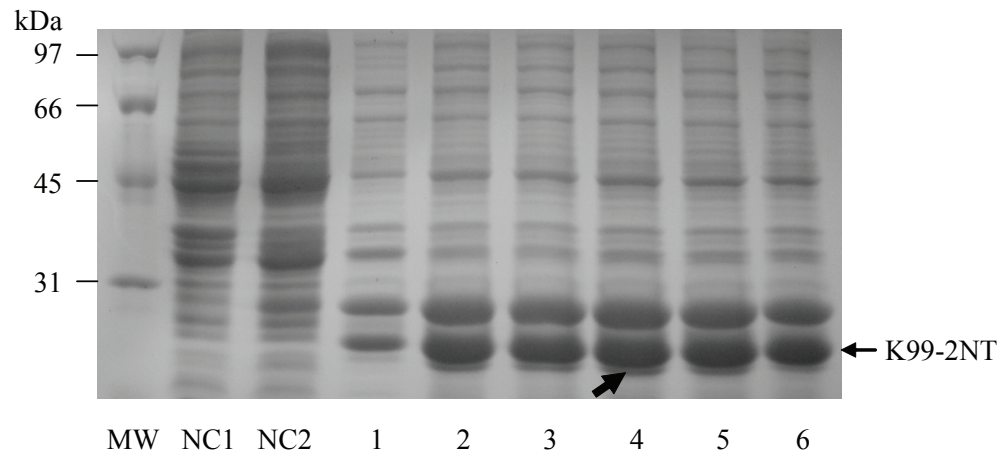

Figure 5. Effect of IPTG concentration on expression level of K99-2NT subunit. MW: protein weight marker (97-14.4 kDa), NC1: non-transformated E. coli cells. NC2: transformated E. coli cells without induction, 1-6: IPTG concentration of $0.05 \mathrm{mM}$, $0.25 \mathrm{mM}, 0.5 \mathrm{mM}, 0.75 \mathrm{mM}, 1 \mathrm{mM}$ and $2 \mathrm{mM}$, respectively. 


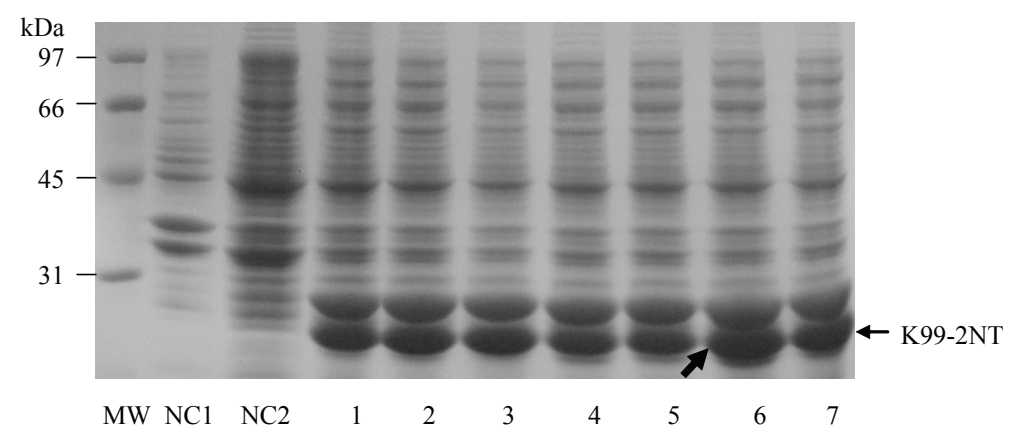

Figure 6. Effect of induction time on expression level of K99-2NT subunit. MW: protein weight marker (97-14.4 kDa), NC1: non-transformated E. coli cells. NC2: transformated E. coli cells without induction, 1-7: induction time from 2-14 h, respectively.

\section{DISCUSSION}

Our results showed that the mature peptide coding sequence of $\operatorname{fan} C-2 \mathrm{NT}$ is $477 \mathrm{bp}$ in length and is $99 \%$ similarity with $\operatorname{fan} C$ gene and K99-2NT subunit of approximately $17.5 \mathrm{kDa}$. According to Roosendaal et al (7), $\operatorname{fan} \mathrm{C}$ gene is $740 \mathrm{bp}$ in length, in which the CDS of 546 bp (from nucleotide 70 to 615) encoding the polypeptide sequence of 181 amino acids with a signal peptide coding sequence of $66 \mathrm{bp}$ (from nucleotide 70 to 135) and a mature peptide coding sequence of $477 \mathrm{bp}$ (from nucleotide 136 to 612). FanC subunit (K99) has 159 amino acids but molecular weight is only $16.5 \mathrm{kDa}$. The CDS of K99 fimbrial subunit precursor from $E$. coli strain NX-K99 has also 546 nucleotides with the deduced sequence of 181 amino acids (8). While Yang et al (9) showed that K99 antigen in strain E. coli SE5000 has molecular weight of $18.5 \mathrm{kDa}$. Study of Tahamtan et al indicated that the CDS of K99 fimbrial subunit precursor from E. coli strain SHI-RAZI 88 is $270 \mathrm{bp}$ in length coding a protein with molecular weight of $9.7 \mathrm{kDa}$ (unpublished). Nasiri et al also cloned the CDS of $\mathrm{K} 99$ fimbrial protein ( $\operatorname{fan} C$ gene) from Escherichia coli strain Mashhad-Iran, this gene is 492 bp in length and its protein molecular weight of approximately $18 \mathrm{kDa}$ (unpublished).

Our previous studies found suitable IPTG concentrations for high expression level of fimbriaes in E. coli BL21 (DE3), such the F107-C (F4) after $14 \mathrm{~h}$ of induction with $0.75 \mathrm{mM}$ IPTG at $37^{\circ} \mathrm{C}$, the K88-1NT (F18) after $6 \mathrm{~h}$ of induction with $0.5 \mathrm{mM} \mathrm{IPTG}$ at $37^{\circ} \mathrm{C}$, and the FasA-13NT (F6) after $8 \mathrm{~h}$ of induction with $0.5 \mathrm{mM}$ at $37^{\circ} \mathrm{C}(17,18)$. However in this work, suitable expression condition of K99$2 \mathrm{NT}$ is slightly different, this protein strongly produced after $12 \mathrm{~h}$ of induction with $0.75 \mathrm{mM} \mathrm{IPTG}$ at $37^{\circ} \mathrm{C}$.

\section{ACKNOWLEDGMENTS}

This study was supported by a grant from the Vietnamese Ministry of Science and Technology (ĐTĐL.2011$\mathrm{T} / 29)$.

\section{REFERENCES}

1. LEE JH, ISAACSON RE 1995 Expression of the gene cluster associated with the E. coli pilus adhesin K99. Infect Immun 63: 4143-4149.
2. ISAACSON RE, PATTERSON S 1994 Analysis of a naturally occurring K99+ enterotoxigenic Escherichia coli strain that fails to produce K99. Infect Immun 62: 4686-4689.

3. JONES GW, ISAACSON RE 1982 Proteinaceous bacterial adhesins and their receptors. Crit Rev Microbiol 10: 229-260.

4. ABE N, MORIISHI K, SAITO M, NAIKI M 1993 Confirmed nucleotide sequence of fan $F$ of Escherichia coli K99 fimbriae. Japanese J Vet Res 41: 97-99.

5. SIMONS LH, WILEMSEN PTJ, BAKKER D, DE GRAAF FK, OUDEGA B 1991 Localization and function of FanH and FanG, minor components of K99 fimbriae of enterotoxigenic Escherichia coli. Microb Pathog 11: 325-336.

6. SIMONS BL, WILLEMSEN PT, BAKKER D, ROOSENDAAL B, DE GRAAF FK, OUDEGA B 1990 Structure, localization and function of FanF, a minor component of K99 fibrillae of enterotoxigenic Escherichia coli. Mol Microbiol 4: 2041-2050.

7. ROOSENDAAL B, GAASTRA W, DE GRAAF FK 1984 The nucleotide sequence of the gene encoding the K99 subunit of enterotoxigenic Escherichia coli. FEMS Microbiol Lett 22: 253-258.

8. LI SG, SHEN ZQ, SHAN H 2007 Cloning and nucleotide sequencing of fusion gene of K99 antigen and heat-stable toxin I of Escherichia coli. Zhongguo Shou Yao Zazhi 4: 11-14.

9. YANG Y, HOU H, YU L, ZHU G 2012 Cloning, expression and activity of K99 fimbrial operon gene from enterotoxigenic Escherichia coli. Acta Microbiologica Sinica 52: 1524-1530.

10. CHU H, KANG S, HA S, CHO K, PARK SM, HAN KH, KANG SK, LEE H, HAN SH, YUN CH, CHOI Y 2005 Lactobacillus acidophilus expressing recombinant $\mathrm{K} 99$ adhesive fimbriae has an inhibitory effect on adhesion of enterotoxigenic Escherichia coli. Microbiol Immunol 49: 941-948.

11. WEN LJ, HOU XL, WANG GH, YU LY, WEI XM, LIU JK, LIU Q, WEI CH 2012 Immunization with recombinant Lactobacillus casei strains producing K99, K88 fimbrial protein protects mice against enterotoxigenic Escherichia coli. Vaccine 30: 3339-3349.

12. WONG I, HERNÁNDEZ A, GARCÍA MA, SEGURA R, RODRÍGUEZI 2002 Fermentation scale up for recombinant K99 antigen production cloned in Escherichia coli MC1061. Process Biochem 37: 1195-1199.

13. OGUNNIYI AD, KOTLARSKI I, MORONA R, MANNING PA 2002 Epitope analysis of the FanC subunit protein of the K99 (F5) fimbriae of enterotoxigenic Escherichia coli using a recombinant fusion technique. FEMS Immunol Med Microbiol 34:23 - 31.

14. PEREIRA DA, SILVA CA, ONO MA, VIDOTTO O, VIDOTTO MC 2015 Humoral immune response of immunized sows with recombinant proteins of enterotoxigenic Escherichia coli. World J Vaccines 5: 60-68.

15. PILLER KJ, CLEMENTE TE, JUN SM, PETTY CC, SATO S, PASCUAL DW, BOST KL 2005 Expression and immunogenicity of an Escherichia coli K99 fimbriae subunit antigen in soybean. Planta 222: 6-18. 
16. GARG R, TOLBERT M, OAKES JL, CLEMENTE TE, BOST KL, PILLER KJ 2007 Chloroplast targeting of FanC, the major antigenic subunit of Escherichia coli K99 fimbriae, in transgenic soybean. Plant Cell Rep 26: 1011-1023.

17. LOC NH, NGOC LMT, LAN TT, VIET LQ, THAO LD, QUANG HT, LAN DTB, LONG PT 2013 Cloning and expression of genes encoding F107-C and K88-1NT fimbrial proteins of enterotoxigenic Escherichia coli from piglets. Indian J Microbiol 53: 488-491.
18. LOC NH, NGOC LMT, TAM DT, QUANG HT, LAN TT, VIET LQ, QUYET PV, LAN DTB, LONG PT 2013 Cloning and expression of gene encoding 987P fimbrial antigen subunit from Escherichia coli 13NT. Proceedings of National Biotechnology Conference, Natural Science and Technology Publishing House, Hanoi, Vietnam 132-136.

19. CARTER GR 1984 Diagnostic procedures in veterinary bacteriology and microbiology, 4th edn. Thomas Publisher, Sprinfield.

20. SAMBROOK J, RUSSELL DW 2001 Molecular cloning. Cold Spring Harbor Laboratory Press, Cold Spring Harbor, New York. 